\title{
LA BIBLIA COMO LUGAR COMÚN
} THE BIBLE AS A COMMON PLACE

Desde hace ya dos décadas que el grupo locus, formado por investigadores de diversas disciplinas en la Universidad de Navarra, viene trabajando entorno a lo que llamamos «lugares», especialmente los «lugares comunes», ese difuso concepto tan fundamental para la comprensión del pensamiento antiguo, medieval y renacentista, y que en buena medida está presente en nuestros días.

Locus es fruto de la convergencia de intereses a partir de trabajos previos, realizados con distintos objetos y en distintos contextos, que tras varios encuentros de estudio cuajaron en un proyecto conjunto. Desde el principio este proyecto se planteó como un estudio sistemático a partir de los lugares de la inventio retórica, para integrar una diversidad de disciplinas que pueden encontrar en ellos un elemento común, y ofrecer una herramienta útil a la comunidad académica. A la vez, estamos desarrollando una reflexión teórica y metodológica sobre el papel que puede tener la incorporación de esa tradición en los debates actuales sobre las disciplinas humanísticas y sobre el conocimiento en general (Zafra y Galván, 2010).

Las reuniones de trabajo de locus se han venido desarrollando a lo largo de los años con muy variados formatos, -congresos, paneles, simposios, cursos de verano,...- en las que se han tratado siempre temas de interés común para nuestras distintas disciplinas, y que han dado resultados de muy distinto tipo -artículos en colaboración, libros editados conjuntamente, ediciones críticas conjuntas,...- pero, sobre todo un muy enriquecedor diálogo que, permeando las distintas especialidades, ha permitido avances singulares en cada una de ellas.

El Dosier que aquí presentamos es el resultado de una serie de estas reuniones de trabajo realizadas en el curso 2018 y 2019, que cuajaron en un curso de verano celebrado en septiembre de 2019. El tema, la Biblia en la tradición cultural y en la cultura contemporánea. Durante las diversas sesiones cada uno de los miembros del grupo fue analizando e interpretando, desde la perspectiva de su disciplina, una manifestación cultural concreta de la Sagrada Escritura, explorando especialmente las zonas de contacto con la de los demás.

Cinco de estos trabajos, previa revisión científica, son los que se presentan en este Dosier sobre la Biblia como lugar cultural. Los cinco analizan un aspecto muy concreto del papel que la Sagrada Escritura ha ejercido, y sigue ejerciendo, como elemento nuclear de ese conglomerado al que seguimos llamando cultura occidental. Los cinco tienen un marcado carácter visual, ya sea porque, como sucede con los poemas navideños de Brodsky, surgieron como imitación poética de un género pictórico -el de las felicitaciones navideñas- o, como en el caso del Libro de Job, ha dado lugar a uno de los personajes icónicos del arte occidental.

Cada uno de los trabajos expone en profundidad un tema de asunto bíblico sin salirse de los límites de la disciplina propia -Literatura, Teología, Historia del Arte, Teoría de la literatura y Emblemática-, pero, aunque a priori parezcan desconectados, una lectura conjunta permite percibir las luces que unos arrojan sobre otros sin que sean necesarias las referencias cruzadas. Referirse unos a otros.

Este es el motivo, por ejemplo, de que hayamos incluido ilustraciones en los dos artículos arriba mencionados -Brodsky y la Navidad y Job o el sufrimiento del justo- pese a que no se haga mención a ellos en texto al que acompañan. La inclusión de estas imágenes en estos textos permite durante la lectura intuir la sutil relación que se establece entre un texto y una imagen que tienen la misma fuente sin que sea necesaria una mención expresa. 


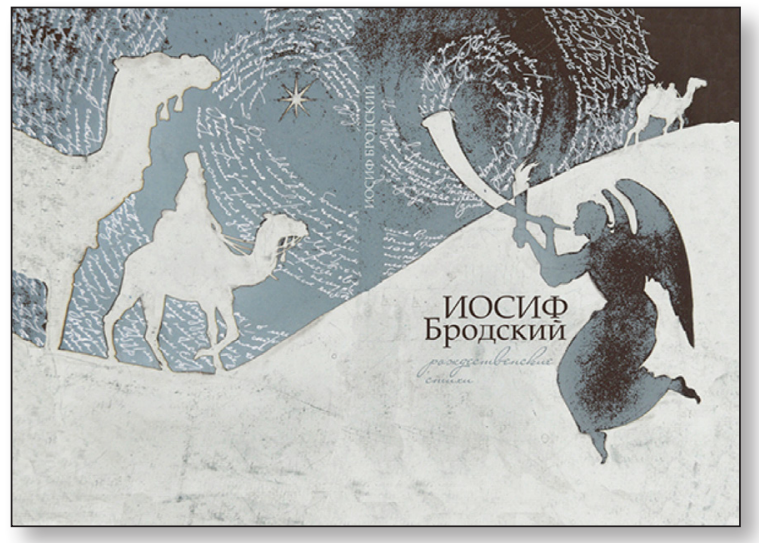

Fig. 1. Guardas para una posible edición rusa de Christmas Verses ilustradas por Sasha Dolzhnitskaya, San Petesburgo.

Son ilustraciones seleccionadas por los editores del dosier de acuerdo con los autores, y tienen como finalidad llamar la atención del lector sobre posibles relaciones que quizá merezca la pena estudiar.

Las preciosas imágenes que acompañan el artículo de Gabriel Insausti «Brodsky y la Navidad», fueron realizadas por Sasha Dolzhnitskaya ${ }^{1}$ para una edición rusa de los Christmas verses del premio Nobel ruso-americano Joseph Brodsky (fig. 1), y han sido incluidas para intentar recrear el ambiente en que se escribieron los poemas. El carácter ecfrástico de estas composiciones es indudable: se compusieron como una suerte de Christmas

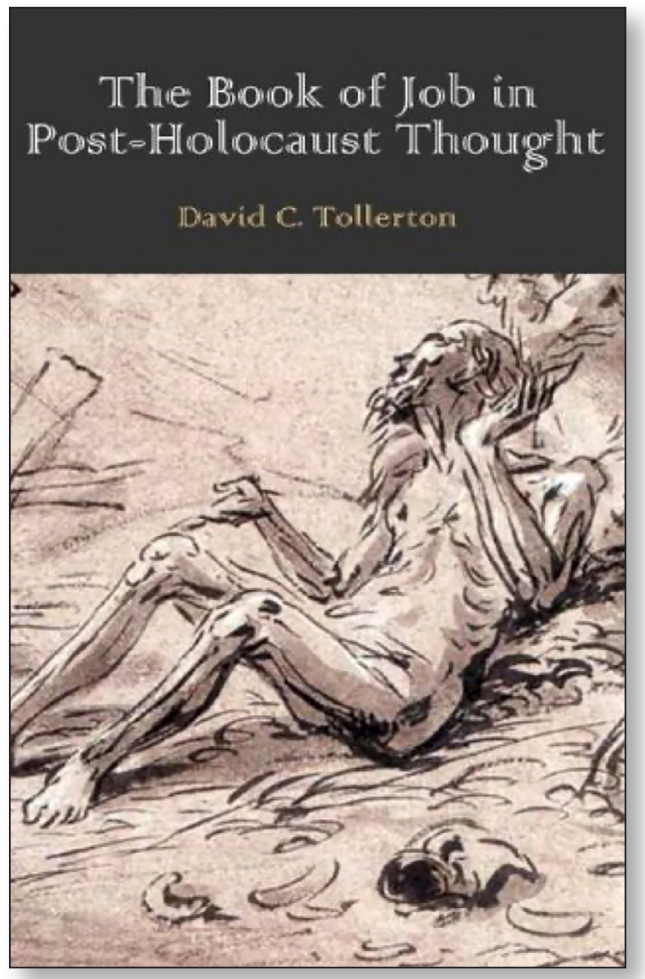

Fig. 2 Portada de David C. Tollerton The book of Job in Post-Holocaust Thought, Sheffield: Sheffield Phoenix Press, 2012. navideños, teniendo incluso alguno una tarjeta navideña como pie compositivo.

El trabajo de Diego Pérez Gondar muestra la complejidad de un libro, el de Job, que no ha sido comprendido en su profundidad hasta los decenios que nos preceden, pese a que ha dado pie a un número ingente de reflexiones, análisis, relatos y obras de arte. La lectura de este trabajo, acompañándolo de algunas de ellas, pretende mostrar que el libro de Job, y su protagonista siguen siendo el emblema de uno de los temas humanos más recurrentes, aún más en nuestro tiempo, especialmente después del Holocausto [fig. 2]: el sufrimiento del inocente.

Los trabajos de Azanza, y Zafra están mucho más evidentemente relacionados con la temática habitual de esta revista por lo que no necesitan de presentación. El de Luis Galván, que ya es autor de Imago con un trabajo muy vinculado al que aquí despliega, se presenta por sí solo. Por ello solo nos queda agradecer a la dirección de IMAGo, encabezada por Rafael Rafael García Mahíques, el habernos facilitado su revista como vehículo para evaluar nuestra investigación y facilitar su difusión entre un publico que es primordialmente al que está destinado.

Rafael Zafra y Luis Galván Universidad de Navarra. Coordinadores y editores del Dosier

1. Agradecemos enormemente a Sasha Dolzhnitskaya que nos haya permitido publicar sus ilustraciones. 